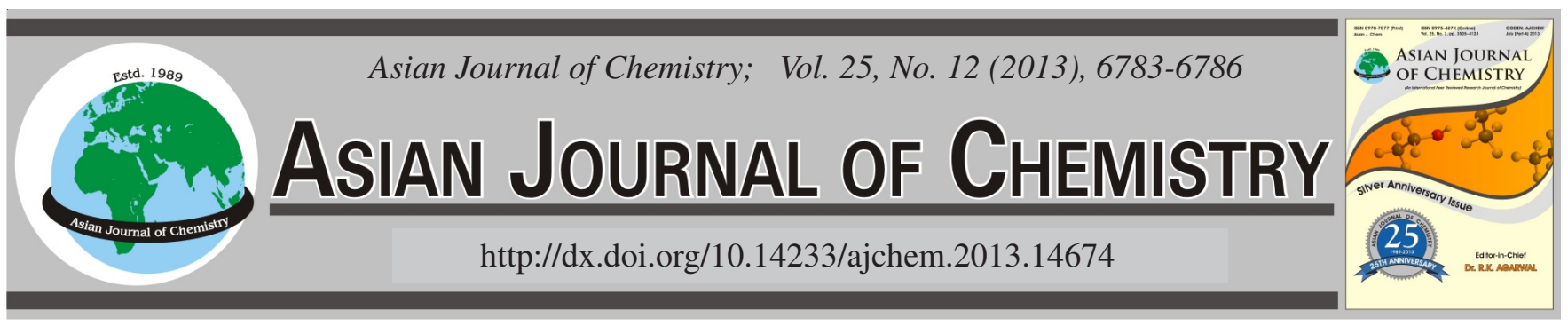

\title{
Design and Synthesis of Two Brucine Derivatives
}

Lauro Figueroa-Valverde ${ }^{1, *}$, Francisco Díaz-Cedillo² ${ }^{2}$, Elodia García-Cervera ${ }^{1}$, Eduardo Pool-Gómez ${ }^{1}$, Abelardo Camacho-Luis ${ }^{3}$, Marcela Rosas-Nexticapan ${ }^{4}$, María López-Ramos ${ }^{1}{ }^{\text {Ivan May-Gil }}{ }^{1}$, Ana Sarao-Alvarez ${ }^{1}$ and Carolina Naal-Dzib ${ }^{1}$

${ }^{1}$ Laboratory of Investigation in Biological Science \& Pharmacochemistry, FacultyofChemicalBiological Sciences, University Autonomic of Campeche, Av. Agustín Melgar, Col Buenavista C.P.24039 Campeche Cam., México

${ }^{2}$ Escuela Nacional de Ciencias Biológicas del Instituto Politécnico Nacional. Prol. Carpio y Plan de Ayala s/n Col. Santo Tomas, D.F. C.P. 11340, México

${ }^{3}$ Facultad de Medicina de la Universidad Juárez del Estado de Durango, es Av. Fanny Anitua s/n Esq. Av. Universidad. C.P. 34000, Durango, Dgo., México

${ }^{4}$ Facultad de Nutrición, Universidad Veracruzana, Médicos y Odontologos s/n C.P. 91010, Unidad del Bosque Xalapa Veracruz, México

*Corresponding author: Fax: +981 8119800; Ext. 73002; Tel: +981 8119800; Ext. 73006; E-mail: lauro_1999@yahoo.com

\begin{abstract}
In this study, two brucine derivative were synthetized; in first stage, the compound 1-\{phenyl-[2-(2,3-dimethoxystrychnidin-10yldeneamino)-ethylamino]-methyl $\}$-naphtalen- 2-ol (4) was development by the reaction of $\beta$-naphthol, $\mathrm{N}^{1}$-(2,3-dimethoxystrychnidin10-yliden)-ethane-1,2-diamine and benzaldehyde in ethanol. Also 4 was prepared by the reaction of brucine with 1-[(2-amino-ethylamino)phenyl-methyl]-naphthalen-2-ol using as catalyst boric acid. In the second stage, the compound 4-hydroxy-N-[2-(2,3-dimethoxystrychnidin10-ylideneamino)-ethyl]benzamide (8) was synthetized by the reaction of 4-hydroxybenzoic acid with $\mathrm{N}^{1}$-(2,3-dimethoxystrychnidin10-yliden)-ethane-1,2-diamine using a carbodiimide derivative as catalyst. Finally, in other experiment the compound $\mathbf{8}$ was also prepared by the reaction of brucine with $\mathrm{N}$-(2-aminoethyl)-4-hydroxybenzamide in presence of a carbodiimide derivative. The structure of all compounds obtained was confirmed by elemental analysis and spectroscopic methods.
\end{abstract}

Key Words: Brucine, Boric acid, $\beta$-Naphthol, Carbodiimide.

\section{INTRODUCTION}

There are studies which show that several derivatives of brucine have been developed for its use in different biological and analytical methods ${ }^{1-4}$. For example, a report shows the synthesis of $\mathrm{N}$-chloromethyl brucine chloride by the reaction of brucine with dichloromethane ${ }^{5}$. Other studies have shown the preparation of a brucine derivative (brucidine) by electrolytic reduction of brucine ${ }^{6}$. In addition, there are reports of the synthesis of $\mathrm{N}$-(5-carboxypentyl)brucinium bromidevia $\mathrm{N}$-alkylation of brucine with 6-bromohexanoic acid ${ }^{7}$. Other experimental data showed the preparation of brucinium hydrogen (S)-malate pentahydrate and anhydrous brucinium hydrogen $(2 \mathrm{R}, 3 \mathrm{R})$-tartrate by the reaction between brucine and D-L-malic acid or L-tartaric acid in ethanol/water ${ }^{8}$. Additionally, the porphyrin-brucine conjugate was synthetized by the $\mathrm{N}$-alkylation of brucine with alkylbromo tetraphenyl porphyrin derivatives ${ }^{9}$. Recently, a brucine derivative $\left(\mathrm{N}^{1}-\right.$-2,3-dimethoxy strychnidin-10-yliden)-ethane-1,2-diamine) was synthetized by the reaction of brucine and ethylenediamine using boric acid as catalyst ${ }^{10}$. Additionally, other study showed the syn- thesis of a brucine-dihydropyrimidine derivative using the multi-component system (brucine, benzaldehyde and thiourea $)^{11}$. All these experimental data show several procedures for synthesis of brucine derivatives. In this study two new brucine derivatives were synthetized using some strategies.

\section{EXPERIMENTAL}

The compounds $\mathrm{N}^{1}$-(2,3-dimethoxystrychnidin-10yliden)-ethane-1,2-diamine (1) and1-[(2-amino-ethylamino)phenyl-methyl]-naphthalen-2-ol (6) was prepared according to previously reported methods ${ }^{10,12}$. The other compounds evaluated in this study were purchased from Sigma-Aldrich Co. Ltd. The melting points for the different compounds were determined on an Electrothermal (900 model). Infrared spectra (IR) were recorded using $\mathrm{KBr}$ pellets on a Perkin Elmer Lambda 40 spectrometer. ${ }^{1} \mathrm{H}$ and ${ }^{13} \mathrm{C}$ NMR spectra were recorded on a Varian VXR-300/5 FT NMR spectrometer at 300 and $75.4 \mathrm{MHz}$ in $\mathrm{CDCl}_{3}$ using TMS as internal standard. EIMS spectra were obtained with a Finnigan Trace GCPolaris Q. spectrometer. Elementary analysis data were acquired from a Perkin Elmer Ser. II CHNS/0 2400 elemental analyzer. 

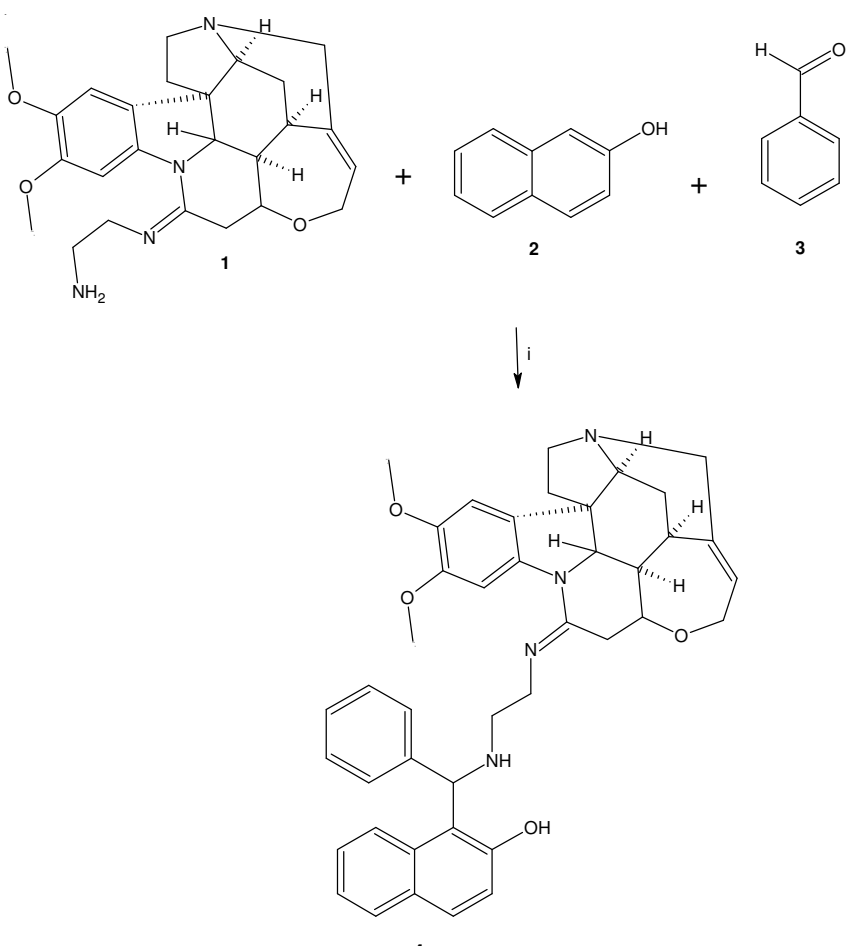

Fig. 1. Synthesis of 1-\{phenyl-[2-(2,3-dimethoxystrychnidin-10yldeneamino)-ethyl-aminol-methyl -naphtalen-2-ol (4). Reaction between $\beta$-naphtol (2), $\mathrm{N}^{1}$-(2,3-dimethoxy- strychnidin-10-yliden)ethane-1,2diamine (1) and benzaldehyde (3) to form $4 . \mathrm{i}=$ ethanol/ $\mathrm{rt}$

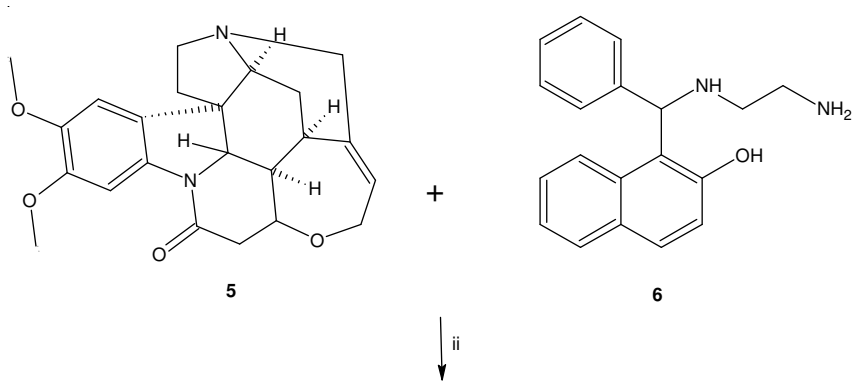

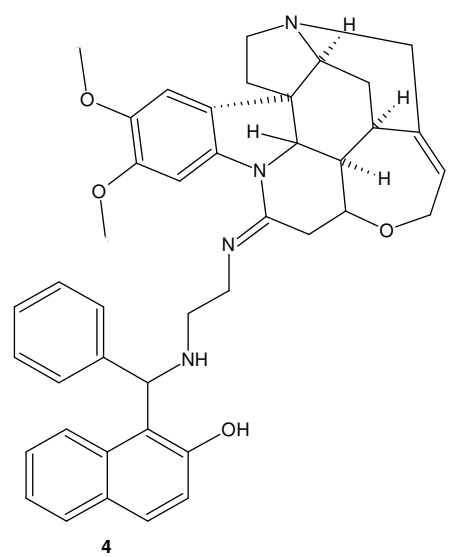

Fig. 2. Synthesis of 1-\{phenyl-[2-(2,3-dimethoxystrychnidin-10yldeneamino)-ethyl-amino]-methyl $\}$-naphtalen-2-ol (4). Reaction betweenbrucine (5) with 1-[(2-amino-ethyl- amino)-phenyl-methyl]naphthalen-2-ol $(\mathbf{6})$ to form 4 . ii $=$ boric acid/rt

1-\{Phenyl-[2-(2,3-dimethoxystrychnidin-10-yldeneamino)-ethylamino]-methyl \}-naph-talen-2-ol (4): A solution of $\beta$-naphthol (40 mg, $0.27 \mathrm{mmol})$, compound $\mathbf{1}$ (100

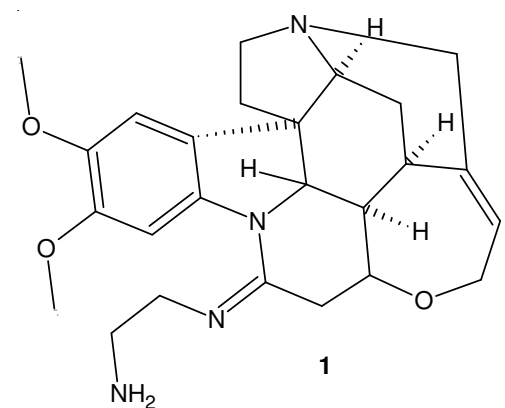<smiles>O=C(O)c1ccc(O)cc1</smiles>

iii

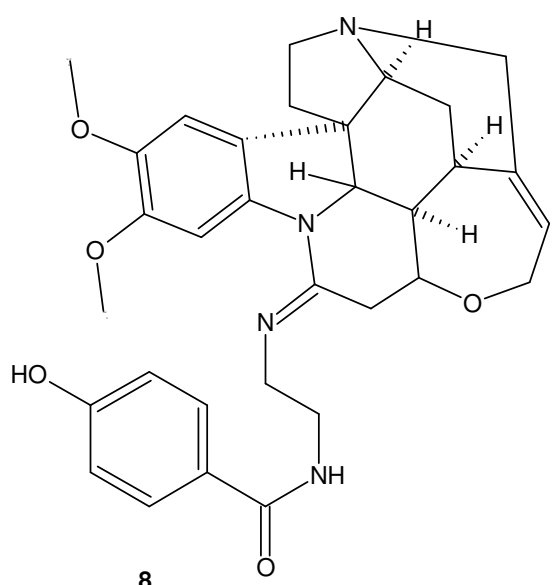

Fig. 3. Synthesis of 4-hydroxy-N-[2-(2,3-dimethoxystrychnidin-10ylideneamino)-ethyl]benzamide (8). Reaction between 4hydroxybenzoic acid (7) with $\mathrm{N}^{1}$-(2,3-dimethoxystrychnidin-10yliden)-ethane-1,2-diamine (1) to form $\mathbf{8}$ using a carbodiimide derivative as catalyst (iii)

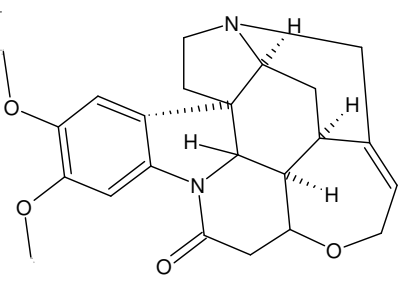

5<smiles>NCCNC(=O)c1ccc(O)cc1</smiles>

9<smiles>[AlH2]</smiles>

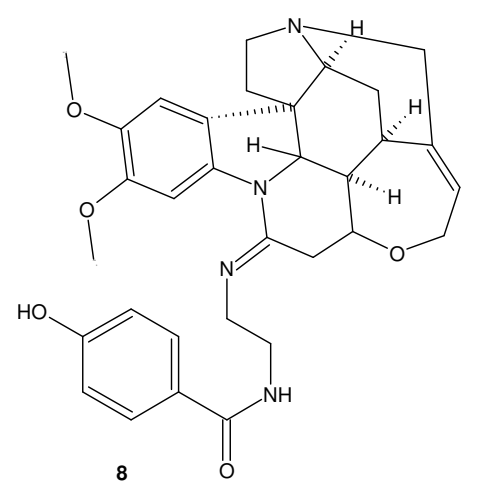

Fig. 4. Synthesis of 4-hydroxy-N-[2-(2,3-dimethoxystrychnidin-10ylideneamino)-ethyl]benzamide (8). Reaction between brucine (5) and $\mathrm{N}$-(2-aminoethyl)-4-hydroxybenzamide (9) to form $\mathbf{8}$ using a boric acid as catalyst (iv) 
$\mathrm{mg}, 0.23 \mathrm{mmol})$ and benzaldehyde $(30 \mu \mathrm{L}, 0.29 \mathrm{mmol})$ in 10 $\mathrm{mL}$ of ethanol was stirring for $72 \mathrm{~h}$ to room temperature. The reaction mixture was evaporated to a smaller volume. After the mixture was diluted with water and extracted with chloroform. The organic phase was evaporated to dryness under reduced pressure, the residue was purified by crystallization from methanol:water (4:1) yielding $33 \%$ of product, m.p. 85 $87{ }^{\circ} \mathrm{C}$; IR (KBr, $\left.v_{\max }, \mathrm{cm}^{-1}\right): 3420,3380,3320 ;{ }^{1} \mathrm{H}$ NMR $(300$ $\left.\mathrm{MHz}, \mathrm{CDCl}_{3}\right) \delta_{\mathrm{H}}: 1.43(\mathrm{~m}, 1 \mathrm{H}), 1.80-1.89(\mathrm{~m}, 2 \mathrm{H}), 2.33-2.37$ $(\mathrm{m}, 2 \mathrm{H}), 2.67-2.74(\mathrm{~m}, 2 \mathrm{H}), 2.82(\mathrm{~m}, 1 \mathrm{H}), 2.90(\mathrm{t}, 1 \mathrm{H}, J=6.4$, $\mathrm{Hz}), 2.95(\mathrm{~m}, 1 \mathrm{H}), 3.02(\mathrm{t}, 2 \mathrm{H}, J=6.4, \mathrm{~Hz}), 3.12(\mathrm{~m}, 1 \mathrm{H})$, 3.26-3.57 (m, 2H), 3.60 (d, $1 \mathrm{H}, J=10.5, \mathrm{~Hz}), 3.62(\mathrm{~m}, 1 \mathrm{H})$, $3.64(\mathrm{t}, 2 \mathrm{H}, J=6.4, \mathrm{~Hz}), 3.66-3.67(\mathrm{~m}, 2 \mathrm{H}), 3.80(\mathrm{~s}, 3 \mathrm{H}), 3.91$ (s, 3H), 4.40 (broad), 4.73(d, $1 \mathrm{H}, J=10.5, \mathrm{~Hz}), 5.07$ (s, 1H), $5.80(\mathrm{~m}, 1 \mathrm{H}), 5.88(\mathrm{~m}, 1 \mathrm{H}), 6.85(\mathrm{~m}, 2 \mathrm{H}), 7.05-7.13(\mathrm{~m}, 3 \mathrm{H})$, $7.22(\mathrm{~m}, 1 \mathrm{H}), 7.43-7.54(\mathrm{~m}, 3 \mathrm{H}), 7.55(\mathrm{~m}, 1 \mathrm{H}), 7.68-7.75(\mathrm{~m}$, 2H) ppm. ${ }^{13} \mathrm{C}$ NMR $\left(75.4 \mathrm{~Hz}, \mathrm{CDCl}_{3}\right) \delta_{\mathrm{C}}: 26.68(\mathrm{C}-17), 28.12$ (C-7), 29.22 (C-18), 39.93 (C-14), 45.60 (C-15), 45.78 (C-3), 50.28 (C-27), 50.44 (C-26), 50.67 (C-11), 52.24 (C-13), 55.50 (C-29), 56.09 (C-43), 56.29 (C-41), 59.29 (C-16), 64.62 (C-8), 65.06 (C-4), 79.27 (C-2), 98.33 (C-20), 105.71 (C-23), 114.39(C-32),121.17 (C-36), 123.37 (C-38), 126.44 (C-37), 127.39(C-47), 127.78 (C-9), 127.96 (C-30), 128.12 (C-34), 128.22 (C-33), 129.02 (C-24), 129.25 (C-49, C-45), 129.27 (C-39), 130.22 (C-48, C-46), 138.15 (C-35), 139.02 (C-19), 139.66 (C-44), 140.51 (C-10), 143.28 (C-22), 147.72 (C-21), 147.84 (C-6), 152.34 (C-31) ppm. EI-MS m/z: $668.06\left(\mathrm{M}^{+}\right.$, 17). Anal. calcd. (\%) for $\mathrm{C}_{42} \mathrm{H}_{44} \mathrm{~N}_{4} \mathrm{O}_{4}$ : $\mathrm{C}, 75.42 ; \mathrm{H}, 6.63 ; \mathrm{N}$, 8.38; O, 9.57. Found (\%) C, 75.40; H, 6.59.

Method B: A solution of brucine (100 mg, $0.25 \mathrm{mmol})$, compound $6(55 \mu \mathrm{L}, 0.25 \mathrm{mmol})$ and boric acid ( $30 \mathrm{mg}, 0.48$ $\mathrm{mmol}$ ) in $10 \mathrm{~mL}$ of ethanol was stirring for $72 \mathrm{~h}$ to room temperature. The reaction mixture was evaporated to a smaller volume. After the mixture was diluted with water and extracted with chloroform. The organic phase was evaporated to dryness under reduced pressure, the residue was purified by crystallization from methanol:water (4:1) yielding $78 \%$ of product. The signals IR, ${ }^{1} \mathrm{H}$ and ${ }^{13} \mathrm{C}$ NMR of brucine derivative (4) were confirmed by spectroscopic analyses as in the first method mentioned above.

\section{4-Hydroxy-N-[2-(2,3-dimethoxystrychnidin-10-ylidene- amino)-ethyl]benzamide (8)}

Method A: A solution of 4-hydroxybenzoic acid (100 $\mathrm{mg}, 0.25 \mathrm{mmol})$, compound $\mathbf{1}(55 \mu \mathrm{L}, 0.25 \mathrm{mmol})$ and 1-ethyl3-(3-dimethylaminopropyl)-carbodiimide hydrochloride (92 $\mathrm{mg}, 0.48 \mathrm{mmol}$ ) in $10 \mathrm{~mL}$ of ethanol was stirring for $72 \mathrm{~h}$ to room temperature. The reaction mixture was evaporated to a smaller volume. After the mixture was diluted with water and extracted with chloroform, the organic phase was evaporated to dryness under reduced pressure, the residue was purified by crystallization from methanol:water (4:1) yielding $74 \%$ of product, m.p. $134-136{ }^{\circ} \mathrm{C}$; IR ( $\left.\mathrm{KBr}, \mathrm{v}_{\max }, \mathrm{cm}^{-1}\right)$ : 3418, 3320, $1674 ;{ }^{1} \mathrm{H}$ NMR $\left(300 \mathrm{MHz}, \mathrm{CDCl}_{3}\right) \delta_{\mathrm{H}}: 1.43(\mathrm{~m}, 1 \mathrm{H}), 1.80-$ $1.89(\mathrm{~m}, 2 \mathrm{H}), 2.33-2.37$ (m, 2H), 2.67-2.74 (m, 2H), 2.82$2.90(\mathrm{~m}, 2 \mathrm{H}), 2.95(\mathrm{~m}, 1 \mathrm{H}), 3.07(\mathrm{t}, 2 \mathrm{H}, J=6.4, \mathrm{~Hz}), 3.12-$ $3.24(\mathrm{~m}, 2 \mathrm{H}), 3.52(\mathrm{~m}, 1 \mathrm{H}), 3.58(\mathrm{t}, 2 \mathrm{H}, J=6.4, \mathrm{~Hz}) 3.64-3.69$ $(\mathrm{m}, 4 \mathrm{H}), 3.80(\mathrm{~s}, 3 \mathrm{H}), 3.85(\mathrm{t}, 2 \mathrm{H}, J=6.4, \mathrm{~Hz}), 3.90(\mathrm{~s}, 3 \mathrm{H})$, $4.70(\mathrm{~d}, 1 \mathrm{H}, J=10.5, \mathrm{~Hz}), 5.48$ (broad, $1 \mathrm{H}), 5.84-5.88$ (m,
2H), $6.89(\mathrm{~m}, 2 \mathrm{H}), 7.55(\mathrm{~m}, 1 \mathrm{H}), 7.68(\mathrm{~m}, 2 \mathrm{H}) \mathrm{ppm} .{ }^{13} \mathrm{C} \mathrm{NMR}$ $\left(75.4 \mathrm{~Hz}, \mathrm{CDCl}_{3}\right) \delta_{\mathrm{C}}: 26.22(\mathrm{C}-17), 28.34(\mathrm{C}-7), 29.22(\mathrm{C}-$ 18), 39.84 (C-14), 40.95 (C-27), 45.65 (C-15), 45.78 (C-3), 50.67 (C-11), 52.20 (C-13), 55.53 (C-26), 56.09 (C-34), 56.29 (C-32), 59.97 (C-16), 64.62 (C-8), 65.06 (C-4), 79.27 (C-2), 98.33 (C-20), 105.71 (C-23), 115.39 (C-37,C-39), 127.80 (C9), 128.44 (C-35), 129.02 (C-34), 129.12 (C-36, C-40), 139.15 (C-19), 140.31 (C-10), 143.28 (C-22), 147.72 (C-21), 147.78 (C-6), 160.43 (C-38), 162.58 (C-29) ppm. EI-MS m/z: 556.05 $\left(\mathrm{M}^{+}, 17\right)$. Anal. calcd. (\%) for $\mathrm{C}_{32} \mathrm{H}_{36} \mathrm{~N}_{4} \mathrm{O}_{5}: \mathrm{C}, 69.05 ; \mathrm{H}, 6.52$; N, 10.06; O, 14.37. Found (\%): C, 68.99; H, 6.49.

Method B: A solution of brucine (100 mg, $0.25 \mathrm{mmol})$, $\mathrm{N}$-(2-aminoethyl)-4-hydroxybenzamide (50 mg, $0.27 \mathrm{mmol}$ ) and boric acid ( $30 \mathrm{mg}, 0.48 \mathrm{mmol}$ ) in $10 \mathrm{~mL}$ of ethanol was stirring for $72 \mathrm{~h}$ to room temperature. The reaction mixture was evaporated to a smaller volume. After the mixture was diluted with water and extracted with chloroform. The organic phase was evaporated to dryness under reduced pressure, the residue was purified by crystallization from methanol:water (4:1) yielding $62 \%$ of product. The signals IR, ${ }^{1} \mathrm{H}$ and ${ }^{16} \mathrm{C}$ NMR of brucine derivative (8) were confirmed by spectroscopic analyses as in the method A mentioned above.

\section{RESULTS AND DISCUSSION}

It is important to mention, that there are many procedures for synthesis of brucine derivatives. Nevertheless, despite its wide scope, the former protocols suffer from several drawbacks because some reagents have a limited stability ${ }^{4-9}$. Therefore, in this study several straight forward routes are reported for the synthesis of two brucine derivatives. The first step involves preparation of $\mathbf{4}$ using the three-component system ( $\beta$-naphthol, benzaldehyde and compound $\mathbf{1}$ ) in ethanol. The ${ }^{1} \mathrm{H}$ NMR spectrum of 4 shows signals at 1.43-2.82, 2.95, 3.26-3.62, 3.66$3.67,4.73$ and $5.80-5.88 \mathrm{ppm}$ for protons involved in the brucine fragment; at 2.90, 3.02 and 3.64 ppm for methylenes present in spacer arm between both imino and amino groups; at 3.80, 3.91 for methoxy groups. Finally, the spectrum contains several signals at 4.40 for both amino and hydroxyl groups; at $5.07 \mathrm{ppm}$ for methylene bound to both amino and phenyl groups; at 6.85-7.75 ppm for phenyl groups. The ${ }^{13} \mathrm{C}$ NMR spectrum contains peaks at chemical shifts of 26.6839.93, 45.78, 50.67-52.24, 59.29-105.71, 128.78, 129.02 . 139.02 and 140.51-147.84 ppm for brucine fragment. Other signals at 50.28-50.44 ppm for methylenesinvolved in spacer arm between both imino and amino groups; at 56.09-56.29 ppm for methoxy groups; at 55.50 for carbon bound to both amine and phenyl groups; at 127.96-128.22, 129.25-138.15 and 139.66-152.34 ppm for phenyls groups were found. Finally, the presence of $\mathbf{4}$ was further confirmed from mass spectrum which showed a molecular ion at $\mathrm{m} / \mathrm{z}$ 668.06. Also the compound 4 was prepared by the reaction of brucine with the compound $\mathbf{6}$ using boric acid as catalyst. It is important to mention that yield of $\mathbf{6}$ was higher with method B in comparison with method A. This phenomenon possibly is due to steric impediment between the reactants or to time of reaction required for the formation of $\mathbf{4}$ in the method $\mathrm{A}$.

In the second stage was achieved by reacting 4hydroxybenzoic acid with the compound 1 resulting in amide 
bond formation involved in the compound $\mathbf{8}$. It is important to mention that many procedures for the formation of amide groups are known in the literature ${ }^{13-15}$. The most widely practiced method employs carboxylic acid chlorides as the electrophiles which react with the amino group in the presence of an acid scavenger ${ }^{16}$. Despite its wide scope, the former protocol suffers from several drawbacks. The most notable are the limited stability of many acid chlorides and the need for hazardous reagents for their preparation (thionyl chloride) ${ }^{17}$. Nevertheless, there are reports which indicate that 1-ethyl-3(3-dimethyl-aminopropyl) carbodiimide hydrochloride catalyzed amidation reaction with high yielding ${ }^{18}$. Therefore, in this work was used carbodiimide-derivative for amide bond formation in a brucine derivative $(\mathbf{8})$. The results indicate that ${ }^{1} \mathrm{H}$ NMR spectrum of $\mathbf{8}$ showed several signals at 1.43-3.52, 3.64-3.69, 4.70, 5.84-5.88 and for $7.55 \mathrm{ppm}$ for brucine nucleus; at 3.58 and 3.85 ppm for arm bound to both amide and imino groups; at 3.80 and $3.90 \mathrm{ppm}$ for methoxy groups; at $5.48 \mathrm{ppm}$ for both amino and hydroxyl groups; at 6.89 and 7.68 ppm for phenyl group. The ${ }^{13} \mathrm{C}$ NMR spectrum contains peaks at chemical shifts of 26.22-39.84, 45.65-52.20, 59.97$105.71,127.80$ and $139.10-147.72 \mathrm{ppm}$ for brucine fragment; at 56.09-56.29 ppm for methoxy groups; at 115.39, 129.12 and $160.43 \mathrm{ppm}$ for phenyl group. Finally, two signals at 147.78 for imino group and $162.58 \mathrm{ppm}$ for amide group were found. In addition, the presence of $\mathbf{8}$ was further confirmed from mass spectrum which showed a molecular ion at $\mathrm{m} / \mathrm{z}$ 556.05 .

On the other hand, the compound $\mathbf{8}$ was also synthetized (method B) by the reaction of the compound 9 with brucine using boric acid as catalyst. It is important to mention that yield of $\mathbf{8}$ was higher with method $\mathrm{A}$ in comparison with method B.

\section{Conclusion}

In this study several strategies for the synthesis of twobrucine derivatives are reported. It is important to mention that some methods used are highly versatile and the yield is good.

\section{REFERENCES}

1. K. Zahn, N. Eckstein, C. Tränkle, W. Sadée and K. Mohr, J. Pharmacol. Exp. Ther., 301, 720 (2002).

2. K.A. Black and P. Vogel, Helv. Chim. Acta, 67, 1612 (1984).

3. H.Y. Kim, H.-J. Shih, W.E. Knabe and K. Oh, Angew. Chem., 121, 7556 (2009).

4. J.W. Show and T.M. Hooker Jr., Can. J. Chem., 56, 1222 (1978).

5. N.J. Birdsall, T. Farries, P. Gharagozloo, S. Kobayashi, S. Lazareno and M. Sugimoto, Mol. Pharm., 55, 778 (1999).

6. S.P. Findlay, J. Am. Chem. Soc., 73, 3008 (1951).

7. K. Záruba and V. Král, Tetrahedron Asym., 13, 2567 (2002).

8. G. Smith, U.D. Wermuth and J.M. White, Acta Cryst., C62, o353 (2006).

9. K. Záruba, J. Králová, P. Rezanka, P. Poucková, L. Veverková and V. Král, Org. Biomol. Chem., 8, 3202 (2010).

10. L. Figueroa-Valverde, F. Díaz-Cedillo, M. López-Ramos, E. GarcíaCervera and E. Pool-Gómez, Asian J. Chem., 24, 2173 (2012).

11. L. Figueroa-Valverde, F. Díaz-Cedillo, M. López-Ramos, E. GarcíaCervera, E. Pool-Gómez and R. Torres-Cutz, Asian J. Chem., 24, 2321 (2012).

12. L. Figueroa-Valverde, F. Díaz-Cedillo, M. López-Ramos, E. GarcíaCervera E. Pool-Gómez, Orient. J. Chem., 28, 1085 (2012).

13. S. Rannard and N. Davis, Org. Lett., 2, 2117 (2000).

14. J.W. Bode and S.S. Sohn, J. Am. Chem. Soc., 129, 13798 (2007).

15. C.R. Hauser and D.S. Hoffenberg, J. Org. Chem., 20, 1448 (1955).

16. A. Medvedeva, M. Andreev, L. Safronova, G. Sarapulova and A. Afonin, Arkivoc, 143 (2001).

17. D. Levin, Org. Process Res. Dev., 1, 182 (1997).

18. N.S. De Silva, I. Ofek and E.C. Crouch, Am. J. Resp. Cell Mol. Biol., 29, 757 (2003). 